Araştırma Makalesi/Research Article

\title{
Opinions of Classroom Teachers about the Use of Argumentation Method in Science Classroom in Primary School
}

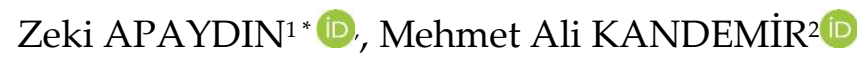 \\ ${ }^{1}$ Ondokuz Mayıs Üniversitesi, Eğitim Fakültesi Temel Eğitim Bölümü, zapaydin@omu.edu.tr \\ 2 Samsun Milli Eğitim Müdürlüğ̈̈, mehmetalikandemir10@gmail.com \\ *Corresponding Author: zapaydin@omu.edu.tr
}

\begin{tabular}{|c|c|}
\hline Article Info & Abstract \\
\hline $\begin{array}{l}\text { Received: } \quad \text { January 31, } 2018 \\
\text { Accepted: } \quad \text { April 20,2018 } \\
\text { Online: } \quad \text { April 30, } 2018 \\
\text { Keywords:Toulmin argumentation } \\
\text { model, argumentation method, } \\
\text { science education. }\end{array}$ & $\begin{array}{l}\text { The purpose of this study is to determine the opinions of classroom } \\
\text { teachers in the elementary school about the use of the argumentation } \\
\text { method appropriate to the Toulmin argumentation model in the science } \\
\text { class. This study was carried out in } 16 \text { hours ( } 8 \text { days) with participation } \\
\text { of } 37 \text { class teachers in Balikesir province of Bandirma. This study is } \\
\text { based on the case study of the qualitative research design. The data was } \\
\text { the result of video recording of semi-structured interviews and semi- } \\
\text { structured interviews with six classroom teachers. The obtained data } \\
\text { was analyzed according to the content analysis which is one of the } \\
\text { analysis methods. At the end of this training, their experiences are } \\
\text { expressed as opinions. According to these views, the method of } \\
\text { argumentation; the students will be interested and attentive, the } \\
\text { students will have a positive attitude towards the classes, the students } \\
\text { will be actively involved in the lessons and learn meaningfully, the } \\
\text { ability to develop scientific thinking skills and to understand the nature } \\
\text { of science can be used not only in science class but also in other courses. }\end{array}$ \\
\hline Mark Cc & $\begin{array}{l}\text { To cite this article: Apaydın, Z. \& Kandemir, M., A. (2018). İlkokulda } \\
\text { sinıf ögretmenlerinin fen bilimleri dersinde argümantasyon yöntemi } \\
\text { kullanımina ilişkin görüşleri. Journal of Computer and Education } \\
\text { Research, } 6 \text { (11), 106-122. https://doi.org/10.18009/jcer.387033 }\end{array}$ \\
\hline
\end{tabular}

\section{İlkokulda Sınıf Öğretmenlerinin Fen Bilimleri Dersinde Argümantasyon Yöntemi Kullanımına İlişkin Görüşleri}

\begin{tabular}{|c|c|}
\hline Makale Bilgisi & Öz \\
\hline $\begin{array}{lcc}\text { Geliş: } & \text { 31 Ocak } 2018 & \\
\text { Kabul: } & 20 \text { Nisan } 2018 & \\
\text { Yayın: } & 30 \text { Nisan } 2018 & \\
\text { Anahtar } & \text { kelimeler: } & \text { Toulmin } \\
\text { argümantasyon } & \text { modeli, } \\
\text { argümantasyon yöntemi, fen eğitimi. }\end{array}$ & $\begin{array}{l}\text { Bu çalışmanın amacı, ilkokulda sınıf öğretmenlerinin fen bilimleri dersinde } \\
\text { Toulmin argümantasyon modeline uygun argümantasyon yönteminin } \\
\text { kullanımına ilişkin görüşlerini belirlemektir. Bu çalışma Balıkesir'in Bandırma } \\
\text { ilçesinde } 37 \text { sınıf öğretmeninin katılımı ile } 16 \text { saatte (8 gün) gerçekleştirilmiştir. } \\
\text { Bu çalışma nitel araştırma yöntemlerinden biri olan durum çalışmasına göre } \\
\text { hazırlanmıştır. Veriler yarı yapılandırılmış görüşme formu ve altı sınff } \\
\text { öğretmeni ile yapılan yarı yapılandırılmış görüşmelerin videoya kaydedilmesi } \\
\text { sonucu edilmiştir. Elde edilen veriler analiz yöntemlerinden biri olan içerik } \\
\text { analizine göre değerlendirilmiştir. Bu eğitim sonunda yaşadıkları deneyimler } \\
\text { sonucunda görüşleri belirtmişlerdir. Bu görüşlere göre argümantasyon } \\
\text { yönteminin; öğrencilerin ilgisinin ve dikkatini çekeceğini, öğrencilerin derslere } \\
\text { karşı olumlu tutum içinde olacağını, öğrencilerin derse aktif olarak katıllp } \\
\text { anlamlı öğrenmeyi gerçekleştireceğini, bilimsel düşünce becerilerini geliştirme } \\
\text { ve bilimin doğasını anlama fırsatı sunacağını, argümantasyon yönteminin } \\
\text { sadece fen bilimleri dersinde değil, diğer derslerde de kullanılabileceğini } \\
\text { belirtmişlerdir (p<.05). }\end{array}$ \\
\hline
\end{tabular}




\title{
Summary
}

\section{Opinions of Classroom Teachers about the Use of Argumentation Method in Science Classroom in Primary School}

\begin{abstract}
Introduction
One of the factors that enable the learning process to be carried out effectively and efficiently is the selection of a method that meets the objectives of the subject. Because the issues are presented to students methods and techniques. All students do not learn the same way. For this reason, it is very important to consider the individual differences of students when choosing a method. Therefore teachers, besides the content knowledge, achievements should have the ability to choose a method that suits the factors such as the characteristics of the students, the class level, the physical conditions of the class, and the fact that the student is active in the learning process. It was found that there were few studies on the use of the argumentation method as a result of the resources I attained, and besides there was no research done on primary school teachers in primary school. Therefore, this study is aimed at shortening the gap in this area and increasing the use of this lesson by introducing this method to the classroom teachers. The purpose of this study is to determine the opinions of class teachers on the use of the argumentation method in the science class.

\section{Method}

This study was carried out in 16 hours (8 days) with participation of 37 class teachers in Balıkesir province of Bandırma in 2016-2017 academic year. This study is based on the case study of the qualitative research design. The data was the result of video recording of semistructured interviews and semi-structured interviews with six classroom teachers. The obtained data was analyzed according to the content analysis which is one of the analysis methods.
\end{abstract}

\section{Results and Discussion}

1. The first of the research questions is "What is the level of knowledge about classroom teachers' method of argumentation?" When Table 1 is examined, it is seen that the 
class teachers who participated in the study hear the name of the argumentation method for the first time and they do not have information about this method and want to have knowledge about this method.

2. The second one from the research questions is "Is classroom teachers taken training on argumentation method?" When Table 1 is examined, it is seen that class teachers are educated by different methods; but they have not previously been trained in the method of argumentation, it is noticed that this training process is the first training on the method of argumentation and that the process is very useful.

3. The third question from the research questions is, "What are the contributions of the argumentation method according to the class teachers?" When examining Table 1, it is seen that classroom teachers reported favorable opinions regarding the contribution of the argumentation method to the cognitive structures of the students. Accordingly, it is clear that the argumentation process will contribute to the elucidation of students' preliminary knowledge, their comparison with their own thoughts, their intensification of attention, motivation, development of research skills, meaningful and lasting learning, elimination of conceptual misconceptions and concept teaching.

a. Teacher views on social contribution of this method; it is seen that students will contribute to improve their speaking skills, to develop social skills, to develop communication skills, to listen to each other, to convince each other, to change their minds and to improve their speaking skills in the community (Table 1).

b. Teacher perspectives on the affective contributions of the argumentation method; it can be said that the argument will be to teach the students how to do the discussion, to help the students to increase their self-esteem, to help each other value their ideas and to enable the students to be open to criticism, by making the course of education and training free from uniformity and making the lesson tasteful, fun and interesting, (Table 1).

c. Teacher's views on the contributions of the argumentation method to develop scientific thinking skills; it can be stated that students will develop their skills of speaking, their scientific process skills, high-level thinking skills, reasoning skills, problem-solving skills, their ability to link claim with evidence among, their ability to support their own beliefs with evidence, their ability to question the thoughts of their and others' friends, and science literacy (Table 1). 
4. The fourth question from the research question is, "What are the limitations of the argumentation method according to the class teachers?" The opinions of class teachers on the limitations of the method of argumentation; it can be seen that the method is too time consuming, it cannot be suitable for all subject topics, it can be excluded from the out of the subject when the boundaries of the discussion cannot be drawn out, the application of the method will fail if the preliminary information is lacking and it will be difficult to implement the method if there is a lot of students presence (Table 1).

5. The fifth of the research questions is "What are the thoughts of classroom teachers about using the argumentation method in class?" Teachers' views on the use of argumentation method in lessons; Except for 29 teachers, that the method could only be used in science classes (Table 1).

As a result, the following suggestions can be made in the light of the findings of the study.

\section{Suggestions}

- The method of argumentation can be used not only in science class, but also in other courses.

- Implementation of the method completely unknown may result in failure. Therefore, teachers can be given theoretical and practical training on the argumentation method which is emphasized especially in the science course of 2017 science course.

- Very few studies have been done on the use of argumentation method in primary school level in our country. Therefore, awareness can be created with new studies on increasing the number of researches on the implementation of the method. 


\section{Giriş}

Öğrenme sürecinin etkili ve verimli bir şekilde gerçekleşmesini sağlayan etmenlerden biri de konunun hedeflerine uygun bir yöntem seçimidir. Çünkü öğretilecek konunun kazanımları seçilecek yöntem ve tekniklerle öğrenciye sunulur (Aykaç, 2005). Öğrencilerin hepsi aynı yöntemle öğrenemediği için konuların kazanımlarına ulaşmada yetersiz kalınabilir, bu nedenle yöntem seçerken öğrencilerin bireysel farklılıklarının (öğrenme stili, ilgi, ön bilgisi vb.) dikkate alınması oldukça önemlidir (Hemlick \& Norland, 1994; Türkben, 2015). Bundan dolayı öğretmenler, içerik bilgisine yönelik donanımlarının yanında; kazanımlar, öğrencilerin özellikleri, sınıf düzeyi, sınıfın fiziki şartları ve öğrenme sürecinde öğrencinin aktif olması gibi faktörleri sağlamaya uygun bir yöntem seçebilme becerisine de sahip olmalıdırlar (Hançer, Şensoy \& Yıldırım, 2003; Saygılı, 2015). Öğrencileri öğrenme sürecinin merkezine alarak öğrencilerin aktif olmasını sağlayan, onların fiziksel ve sosyal çevreleriyle etkileşerek öğrenmelerine fırsat sunan yöntemlerin kullanılması; etkili bir eğitim ve öğretim süreci için önemlidir (Aykaç, 2011).

Öğrencilerin eğitim ve öğretim sürecine aktif olarak katıldığı yöntemlerden biri de argümantasyon yöntemidir (Köseoğlu, Tümay \& Budak, 2008). Argümantasyon yöntemi ile ilgili alan yazında birçok tanımlama mevcuttur. Bunlardan bazıları şunlardır: "Argümantasyon bilimde ve gerçek yaşamda gerekçeler belirtilerek iddiaların kanıtlar ile desteklenip geçerlenmesidir" (Toulmin, 2003). Öğrencilere, ortaya koydukları iddiaları kanıtlarla destekleme ve gerekçelendirme, düşüncelerini doğrulama yada çürütme fırsatının verildiği bir süreçtir (Demircioğlu \& Uçar, 2012). Argümantasyon yöntemini tanımlayan taslaklar içinde en kapsayıcı olan Toulmin (1958) tarafından geliştirilmiş olan argümantasyon modelidir (Çepni, 2016). Bu model sayesinde, argümantasyon öğretimde etkin olarak kullanılmaya başlanmıştır (Aldağ, 2006). Toulmin (1958), tarafından geliştirilen bu model öğretmenlerin ve öğretmen adaylarının argümantasyon yöntemini tanımasına fırsat tanımaktadır (Kaya \& Kılıç, 2008). Bu modelde altı tane bileşen vardır. Bu bileşenlerden iddia, veri ve gerekçe temel bileşenler; sınırlayıcı, çürütüçü (reddedici) ve destekleyici ise yardımcı bileşenlerdir (Çepni, 2016; Erduran, Simon \& Osborne, 2004).

İddia, bir soru ya da problemin çözümüne ilişkin görüşler; hipotezler; veri, iddiayı desteklemek için kullanılan kanıtlardır. Gerekçe, veriler ile iddialar arasındaki ilişkiyi açıklayan ifadelerdir. Destekleyici, iddiayı kuvvetlendiren ek kanıtlardır. Niteleyici, sunulan 
kanıtların doğru olabileceğini belirten ifadelerdir (her zaman, genellikle, nadiren). Çürütücü, iddianın geçerli olmadığı durumları gösteren ifadelerdir (Apaydın, Peker \& Taş, 2012; Çepni, 2016; Toulmin, 2003; Tümay \& Köseoğlu, 2011).

$\mathrm{Bu}$ yöntemin avantajları; bilimsel süreç becerilerinin, bilim okuryazarlığının gelişmesini ve bilimin doğasını algılamayı sağlar, öğretmen ve öğrencilerin kendilerini ifade etme becerilerinin gelişmesine fırsat verir, anlamlı öğrenmeyi kolaylaştırır, öğrencilerin öğrenme sürecine aktif katılımını sağlar, motivasyonu arttırır, öğrencileri değerlendirme fırsatı sunar, öğrencilerin kendi düşünleri ile başkalarının düşünceleri arasındaki benzerlik ve farklılıkları görmelerini sağlar, öğrencilerin birbirlerinin düşüncelerine değer vermesini sağlar ve ayrıca öğrencilerin süreç içinde saygı ve sevgi çerçevesinde birbirlerini ikna ederek düşüncelerini değiştirmelerini, iletişim becerilerinin ve eleştirel düşünmenin gelişimini olanaklı kılar, dersi zevkli ve eğlenceli hale getirerek öğrencinin ilgisini arttırır, kavram yanılgılarını giderilmesine katkı verir, özgüveni arttırır ve sorgulama becerilerini geliştirir (Çepni, 2016; Erduran \& ve diğ., 2004; Kaptan \& Aydın, 2014; Michaels, Schweingrber \& Shouse, 2008; Tümay \& Köseoğlu, 2011).

Bu yöntemin, avantajları yanında sınırlılıkları da vardır. Bunlar; uzun zaman alması, öğrencilerde ön bilgi gerektirmesi öğretmenlerin kendilerini bu konuda yetersiz hissetmeleri ve dolayısıyla yöntemi kullanmaya yönelik olumsuz tutum içinde olmaları, öğrenci sayısının fazla olmasının yöntemin uygulanmasını güçleştirmesi, konu sınırlarının iyi belirlenmediği durumlarda kapsam dışına çıkılabilmesi, öğrencilerin görüşlerinde ısrarcı davranmaları, tartışmada modele uygun bir sıranın takip edilememesi ve bu durumun verilerin analizini zorlaştırması şeklinde sıralanabilir (Aydın \& Kaptan, 2014; Çepni, 2016; Driver, Newton \& Osborne, 2000). Ulaştığım kaynaklar neticesinde argümantasyon yönteminin kullanımına ilişkin az sayıda çalışma olduğu görülmüş, bunun yanında ilkokulda sınıf öğretmenlerine yönelik yapılan bir araştırmaya rastlanılmamıştır. Bundan dolayı, bu çalışma bu alandaki eksikliği gidermek ve sınıf öğretmenlerine bu yöntemi tanıtarak derslerde bu kullanımını arttırmaya yöneliktir.

\section{Araştırmanın Amacı}

$\mathrm{Bu}$ çalışmanın amacı, sınıf öğretmenlerinin fen bilimleri dersinde argümantasyon yönteminin kullanılmasına ilişkin görüşlerini belirlemektir. Bu genel amaç doğrultusunda aşağıdaki araştırma sorularına yanıtlar aranmıştır.

- Sınıf öğretmenlerinin argümantasyon yöntemi hakkında bilgi düzeyleri nedir? 
- Sınıf öğretmenlerinin argümantasyon yöntemiyle ilgili eğitim alma durumları nedir?

- Sınıf öğretmenlerine göre argümantasyon yönteminin avantajları nelerdir?

- Sınıf öğretmenlerine göre argümantasyon yönteminin sınırlılıkları nelerdir?

- Sınıf öğretmenlerinin argümantasyon yöntemini fen bilimleri dersinde ve diğer derslerde kullanmaya yönelik görüşleri nelerdir?

\section{Yöntem}

\section{Çalışma Grubu}

Araştırma, Balıkesir'in Bandırma ilçesinde 2017-2018 eğitim ve öğretim yılında aynı okuldan 37 sınıf öğretmeninin katılımı ile gerçekleştirilmiştir. Çalışma grubunun belirlenmesinde uygun örnekleme yöntemi kullanılmıştır. Uygun örneklemede, kolay ulaşılabilen bir çalışma grubu seçilebilir (Büyüköztürk, Çakmak, Akgün, Demirel \& Karadeniz, 2016).

\section{Araştırmanın Deseni}

$\mathrm{Bu}$ çalışma nitel araştırma desenlerinden biri olan durum çalışmasına göre düzenlenmiştir. Çalışmada sınıf öğretmenleri için fen bilimleri dersine yönelik argümantasyon yöntemi kullanımı eğitimi temel durum olarak alınmış ve bu eğitime katılan sınıf öğretmenlerinden argümantasyon yöntemine yönelik görüşleri alınmıştır. Durum çalışmasının en önemli özelliği; araştırmacıya konu ya da durum oluşturan olgular üzerinde yoğunlaşma, elde edilen verileri derinlemesine ve ayrıntılı olarak açıklayabilme fırsatı sunmasıdır (Çepni, 2010).

\section{Ĕgitim ve Öğretimin Uygulanması}

Seçilen öğretmenlere uygulama öncesi ve uygulama sonrası görüşme formu uygulanmıştır. Uygulama öncesinde, formdan elde edilen veriler neticesinde; öğretmenlerin hepsinin argümantasyon yöntemi ile ilgili hiç bir eğitim almadıkları ve bu konuda bilgilerinin olmadığı belgelenmiştir. Bir sonraki aşamada sınıf öğretmenlerine “Toulmin argümantasyon modeli nedir?”, “Toulmin argümantasyon modelinin öğeleri ve bunlar arasındaki ilişkiler nelerdir?", “Toulmin argümantasyon modelinin özellikleri nelerdir?”, “Toulmin argümantasyon modeli fen bilimleri dersinde nasıl uygulanır?", “Toulmin argümantasyon modelinde değerlendirme nasıl yapılır?" gibi konularda sekiz gün, günde iki saat olmak üzere teorik ve uygulama eğitimi verilmiştir. Teorik bilgilendirmenin ardından, uygulama eğitiminde 3 . ve 4 . sınıf fen bilimleri derslerinin konularından sağlanan içerik 
bilgisi kullanılmıştır. Öğretmenler altışar kişiden oluşan gruplara ayrılmış, konular ile ilgili bireysel olarak modele uygun olarak argümanlarını kurmuş, argümanlar grup içinde tartışılmış ve görüş birliğine varılan argümanlar diğer gruplardaki öğretmenlerle paylaşılarak tekrar tartışılmıştır. Uygulama öğretmeni ve gönüllü diğer öğretmenler uygulama süresince rehberlik görevini üstlenmişlerdir. Eğitim sürecinin ardından görüşme formu ve video çekimleri aracılığıyla, öğretmenlerin argümantasyon yöntemi ile ilgili görüşleri alınmıştır.

\section{Veri Toplama Araci}

$\mathrm{Bu}$ araştırmada veriler araştırmacıların geliştirdiği yarı yapılandırılmış görüşme formundan ve 6 gönüllü sınıf öğretmeniyle yapılan görüşmelerin video kayıtlarından elde edilmiştir. Form ve video kaydı aracılıyla öğretmenlerin argümantasyon yöntemine yönelik görüşleri alınmıştır. Görüşme formunda; argümantasyon yönteminin katkıları, argümantasyon yönteminin derslerde kullanılabilme durumu, argümantasyon yönteminin sınırlılıkları, argümantasyonla ilgili eğitim, argümantasyon bilgisi konularına yönelik sorular bulunmaktadır. Görüşme formu hazırlanırken soruların açık ve anlaşılır olmasına ve yanıtlayan kişi üzerinde yönlendirici bir etkisisin olmamasına dikkat edilmiştir (Akt.: Büyüköztürk ve diğ., 2016; Brewerton \& Millward, 2001; Fraenkel \& Wallen, 2006). Geliştirilen görüşme formunun amaca ne derece hizmet etiğini belirlemek için alan uzmanın görüşü alınmış, gerekli düzeltmeler yapılmıştır. Ayrıca form uygulamaya katılmayacak beş sınıf öğretmenine, anlayamadıkları yerler olup olmadığını belirlemek için okutulmuştur.

Görüşmelerde ve görüşme formu yanıtlanırken süre olabildiğince uzun tutularak iç geçerlilik sağlanmaya çalışılmıştır. Ayrıca araştırmadan elde edilen verilerin görüşme formunun kavramsal çerçevesine uygunluğu sürekli kontrol edilmiştir. Araştırma sürecinde yapılan işlemler ayrıntılı olarak verilerek dış geçerlilik arttıılmaya çalışılmıştır. Araştırmanın iç tutarlığını artırmak amacıyla bulgular yorum yapılmadan verilmiştir (Yildırım \& Şimşek, 2008).

\section{Verilerin Analizi}

Video ve formlardan elde edilen veriler içerik analizi tekniği ile değerlendirilmiştir. $\mathrm{Bu}$ teknik çoğunlukla sosyal bilimler alanında yapılan araştırmalarda kullanılmaktadır. İçerik analizi, belirli kurallara bağlı kodlamalarda metin veya metinlerin içindeki bazı sözcüklerin kategoriler şeklinde özetlendiği sistematik bir tekniktir. Yalnızca metinlerde de değil; görüşmelerde, tartışmalarda da kullanılabilir (Büyüköztürk ve diğ., 2016). Video ve 
formlar incelenerek elde edilen veriler 1'den 43'e kadar numaralandırılmıştır. Video ve formlardan elde edilen verilere yönelik kodlar oluşturulmuş, kodlar bir araya gelerek kategoriler (temalar) ve alt kategoriler oluşturularak içerik analizi yapılmıştır (Yıldırım \& Şimşek, 2008).

İçerik analizinde iç tutarlığı belirlemek amacıyla bir ya da birkaç kişinin kodlama yapması ve sonuçların karşılaştırılması gerekir. Bu amaçla kura usulü seçilen iki tane araştırmacıdan elde edilen verilerin kodları ve kodlara ilişkin kategoriler ve alt kategoriler karşılaştırılmış, tutarlılık yüzdesi \% 90 olarak hesaplanmıştır ( iki formda aynı kodlanan madde sayısı/ bir formda bulunan toplam madde sayısı) ${ }^{*} 100=$ Tutarlılık yüzdesi) ( Miles \& Huberman, 1994). İç tutarlılık için \% 70 yeterli kabul edilmektedir ( Yıldırım \& Şimşek, 2008).

\section{Bulgular}

Verilerin analizi sonucu elde edilen kod ve kategoriler aşağıdaki tabloda verilmiştir.

Tablo 1. Sınıf Öğretmenlerinin Argümantasyon Yöntemine İlişkin Görüşlerinin Değerlendirilmesi Sonucu Elde Edilen Kod, Kategori ve Frekans Dağılımı

Kategoriler

Alt Kategoriler

Kodlar

菊

\begin{tabular}{|c|c|c|c|c|}
\hline \multirow{3}{*}{1.} & \multirow{3}{*}{$\begin{array}{l}\text { Argümantasyon } \\
\text { Bilgisi }\end{array}$} & & \multirow{2}{*}{$\begin{array}{l}\text { Argümantasyon yöntemi hakkında bilgi sahibi değilim. } \\
\text { Argümantasyon yöntemi adını daha önce hiç duymadım. }\end{array}$} & \multirow{2}{*}{37} \\
\hline & & & & \\
\hline & & & $\begin{array}{llll}\begin{array}{l}\text { Argümantasyon yöntemini hakkında bilgi edinmek } \\
\text { istiyorum. }\end{array} & & & \\
\end{array}$ & 35 \\
\hline \multirow[t]{3}{*}{2.} & \multirow{3}{*}{$\begin{array}{l}\text { Argümantasyonla } \\
\text { İlgili Eğitim }\end{array}$} & & $\begin{array}{l}\text { Argümantasyon yöntemi ile ilgili daha önce hizmet içi } \\
\text { eğitim almadım. }\end{array}$ & 37 \\
\hline & & & Verilen eğitimin faydalı olduğunu düşüyorum. & 37 \\
\hline & & & Argümantasyon yöntemi ile ilgili ilk defa eğitim alıyorum. & 37 \\
\hline \multirow{5}{*}{3.} & \multirow{5}{*}{$\begin{array}{l}\text { Argümantasyon } \\
\text { Yönteminin } \\
\text { Sınırlılıkları }\end{array}$} & & Bu yöntemin çok zamanımı alıyor. & 12 \\
\hline & & & Bu yöntem bütün konularda kullanılmıyor. & 13 \\
\hline & & & $\begin{array}{l}\text { Tartışmada konu sınırları belirlenmediği takdir de konu } \\
\text { dışına çıkılır. }\end{array}$ & 11 \\
\hline & & & $\begin{array}{l}\text { Bu yöntemin uygulama öncesi öğrencilerin ön bilgi eksikleri } \\
\text { olması durumunda yöntemin uygulaması başarısızlıkla } \\
\text { sonuçlanır. }\end{array}$ & 12 \\
\hline & & & Sınıf mevcudunun fazla olmasından uygulaması zorlaşır. & 11 \\
\hline \multirow[t]{5}{*}{4.} & \multirow{5}{*}{$\begin{array}{l}\text { Argümantasyon } \\
\text { Yönteminin } \\
\text { Derslerde } \\
\text { Kullanılma } \\
\text { Durumu }\end{array}$} & & Bu yöntemi sadece fen bilimleri dersinde kullanacağım. & 8 \\
\hline & & & $\begin{array}{l}\text { Bu yöntemi birden çok derste kullanacağım (fen bilimleri } 29, \\
\text { matematik 23, hayat bilgisi ve sosyal bilgiler } 29 \text {, Türkçe, } 15 \\
\text { sinıf öğretmeni). }\end{array}$ & 29 \\
\hline & & \multirow{3}{*}{ Bilişsel katkıları } & $\begin{array}{l}\text { Öğrencilerin ön bilgilerini ortaya çıkarılmasına yardımcı } \\
\text { olur. }\end{array}$ & 25 \\
\hline & & & $\begin{array}{l}\text { Öğretmenlerin, öğrencilerin derste ne anladıklarını } \\
\text { değerlendirmelerine yardımcı olur. }\end{array}$ & 23 \\
\hline & & & $\begin{array}{l}\text { Öğrencilerin kendi düşünceleri ile diğerlerinin düşünceleri } \\
\text { arasındaki benzerlik ve farklılıkları görmelerini sağlar. }\end{array}$ & 30 \\
\hline
\end{tabular}




\begin{tabular}{|c|c|c|c|c|}
\hline \multirow{12}{*}{\multicolumn{2}{|c|}{$\begin{array}{l}\text { Argümantasyon } \\
\text { Yönteminin } \\
\text { Katkıları }\end{array}$}} & & $\begin{array}{l}\text { Eğitim ve öğretim sürecini öğrencilerin dikkatini çekmede } \\
\text { kolaylık sağlar. }\end{array}$ & 28 \\
\hline & & & $\begin{array}{l}\text { Öğrencilerin eğitim ve öğretim sürecinde güdülenmesini } \\
\text { kolaylaştırır. }\end{array}$ & 29 \\
\hline & & & Kavram yanılgılarının giderilmesine yardımcı olur. & 25 \\
\hline & & & Kavram öğretimin kolaylaşması sağlar. & 30 \\
\hline & & & Araştırma becerisi gelişir. & 30 \\
\hline & & & $\begin{array}{l}\text { Anlamlı ve kalıcı izli öğrenmeyi sağladığı için akademik } \\
\text { başarıyı arttırır. }\end{array}$ & 30 \\
\hline & & \multirow{6}{*}{ Sosyal katkıları } & Öğrencilerin kendilerini ifade etme becerileri gelişir. & 34 \\
\hline & & & Öğrencilerin sosyalleşmesini sağlar. & 28 \\
\hline & & & İletişim becerilerini geliştirme imkânı sunar. & 24 \\
\hline & & & Öğrencilerin birbirlerini dinlemesini sağlar. & 25 \\
\hline & & & $\begin{array}{l}\begin{array}{l}\text { Öğrenciler birbirlerini } \\
\text { değiştirmeyi sağlar. }\end{array} \\
\text { lkna }\end{array}$ & 24 \\
\hline & & & Toplum önünde konuşma becerisini geliştirir. & 26 \\
\hline & & \multirow{8}{*}{ Duyuşsal katkıları } & Eğitim ve öğretim sürecini tekdüzelikten kurtarır. & 26 \\
\hline & & & Öğrencilerin ilgisi çeker. & 26 \\
\hline & & & Dersi daha eğlenceli, zevkli ve çekici hale getirir. & 26 \\
\hline & & & Derslere karşı olumlu tutum geliştirilmesini sağlar. & 26 \\
\hline & & & $\begin{array}{l}\text { Tartışma yaparken } \text { birbirlerini } \\
\text { öğrenirler. }\end{array}$ & 30 \\
\hline & & & Öğrencilerin kendine olan güvenini arttırır. & 28 \\
\hline & & & Öğrencilerin birbirlerinin fikirlerine değer vermesini sağlar. & 27 \\
\hline & & & Öğrencilerin eleştiriye açık olmasını sağlar. & 27 \\
\hline & & \multirow{14}{*}{$\begin{array}{l}\text { Bilimsel düşünme } \\
\text { becerilerine katkıları }\end{array}$} & $\begin{array}{l}\text { Bilimin doğasının anlaşılmasına (değişken yapısı) yardımcı } \\
\text { olur. }\end{array}$ & 23 \\
\hline & & & Bilişsel düşünme becerisinin gelişmesini sağlar. & 24 \\
\hline & & & $\begin{array}{l}\text { Öğrencilere eleştirel, yaratıcı, yansıtıcı düşünme vb. gibi üst } \\
\text { düzey olan düşünme süreçleri geliştirebileceği süreçler } \\
\text { sunar. }\end{array}$ & 27 \\
\hline & & & $\begin{array}{l}\text { Öğrencilerin düşünceleri hakkında konuşmalarına ve } \\
\text { düşüncelerini bilimsel temellere dayandırmasına imkân } \\
\text { sağlar. }\end{array}$ & 21 \\
\hline & & & Problem çözme becerisi gelişir. & 23 \\
\hline & & & Ak1l yürütme becerilerini geliştirir. & 23 \\
\hline & & & $\begin{array}{l}\text { Öğrencilere iddia ve kanıtlar arasında bağlantılar kurmasına } \\
\text { teşvik eder. }\end{array}$ & 37 \\
\hline & & & $\begin{array}{l}\text { Öğrencilerin kendi düşüncelerini kantlarla desteklemeyi } \\
\text { öğrenir. }\end{array}$ & 37 \\
\hline & & & Bilimsel bilginin üretilme süreci anlamasını sağlar. & 26 \\
\hline & & & 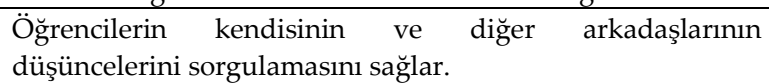 & 32 \\
\hline & & & Öğrencilerin düşüncelerini savunma becerisi gelişir. & 30 \\
\hline & & & Öğrencilerin tartışma becerilerini geliştirmesine imkân tanır. & 32 \\
\hline & & & Öğrencilerin bakış açısını geliştirir. & 14 \\
\hline & & & Bilimsel okuryazarlığı geliştirme fırsatı sağlar. & 32 \\
\hline
\end{tabular}

1. Araştırma sorularından birincisi, "Sınıf öğretmenlerinin argümantasyon yöntemi hakkında bilgi düzeyleri nedir?" sorusudur. Tablo 1 incelendiğinde çalışmaya katılan 37 sınıf öğretmenin argümantasyon yönteminin adını ilk defa duydukları ve bu yöntem hakkında bilgi sahibi olmadıkları, 35 sınıf öğretmeninin ise bu yöntem hakkında bilgi sahibi olmak istedikleri gözlenmektedir. 
2. Araştırma sorularından ikincisi, "Sınıf öğretmenlerinin argümantasyon yöntemiyle ilgili eğitim alma durumları nedir?" sorudur. Tablo 1 incelendiğinde 37 sinıf öğretmenin farklı yöntemlerle eğitim aldıkları; ancak argümantasyon yöntemi ile ilgili daha önce eğitim almadıkları; aldıkları eğitimin argümantasyon yöntemi ile ilgili ilk eğitim olduğu ve verilen eğitimin çok yaralı olduğu yönünde açıklamalarda bulundukları görülebilir.

3. Araştırma sorularından üçüncüsü, "Sınıf öğretmenlerine göre argümantasyon yönteminin avantajları nelerdir?" sorusudur. Tablo 1 incelendiğinde sınıf öğretmenlerinin argümantasyon yönteminin bilişsel katkılarına yönelik görüşleri; 25 sınıf öğretmeni için, yöntemin öğrencilerin ön bilgilerinin ortaya çıkarılmasına, 23 sınıf öğretmeni için, öğrencilerin değerlendirilmesine, 30 sınıf öğretmeni için, öğrencilerin kendi düşünlerini diğerlerinin düşünceleriyle karşılaştırmasına, 28 sınıf öğretmeni için, öğrencilerin dikkatini çekmeye, 29 sinıf öğretmeni için, öğrencilerin güdülenmesine, 25 sinıf öğretmeni için, öğrencilerin kavram yanılgılarının giderilmesine, 30 sınıf öğretmeni için, öğrencilerin anlamlı, kalıcı öğrenmesine ve kavram öğreniminin etkili olmasına, 30 sınıf öğretmeni için ise, öğrencilerin araştırma becerilerinin gelişimine katkı sunacağ yönündedir.

Sınıf öğretmenlerinin argümantasyon yönteminin sosyal katkılarına yönelik görüşleri incelendiğinde; 34 sınıf öğretmeni öğrencilerin kendilerini ifade etme becerisini geliştireceğini, 28 sınıf öğretmeni öğrencilerin sosyalleşmesini sağlayacağını, 24 sınıf öğretmeni öğrencilerin iletişim becerisini geliştireceğini, 25 sınıf öğretmeni öğrencilerin birbirini dinlemesini sağlayacağını, 24 sınıf öğretmeni öğrencilerin birbirlerini ikna ederek düşüncelerini değiştirmesini sağlayacağını belirtirken; 24 sınıf öğretmeni de öğrencilerin toplum önünde konuşma becerilerini değiştirmeye fırsat tanıyacağını ifade etmişlerdir.

Sınıf öğretmenlerinin argümantasyon yönteminin duyuşsal katkılarına yönelik görüşleri incelendiğinde; 26 sınıf öğretmeninin eğitim ve öğretim sürecini tek düzelikten kurtarıp dersi zevkli, eğlenceli, ilgi çekici hale getirip öğrencilerin olumlu tutum geliştirmelerini sağlayacağını, 30 sınıf öğretmeninin öğrencilerin birbirini kırmadan tartışmanın nasıl yapılması gerektiğini öğreneceğini, 28 sınıf öğretmeninin öğrencilerin özgüvenini arttıracağını, 27 sınıf öğretmeninin öğrencilerin birbirlerinin fikirlerine değer vermesini sağlayacağını, 27 sınıf öğretmeninin öğrencilerin eleştiriye açı olmasını sağlayacağını belirttikleri ifade edilebilir.

Sınıf öğretmenlerinin argümantasyon yönteminin bilimsel düşünme becerilerini geliştirmeye yönelik katkılarına ilişkin görüşleri değerlendirildiğinde; 23 sınıf öğretmeni 
argümantasyonun öğrencilerin bilimin doğasını anlama becerisini, 24 sınıf öğretmeni bilimsel düşünme becerilerini, 27 sınıf öğretmeni üst düzey düşünme becerilerini, 21 sınıf öğretmeni düşünceleri bilimsel temellere dayandırma becerisini, 23 sınıf öğretmeni akıl yürütme becerilerini, 37 sınıf öğretmeni iddialarla kanıtlar arasında bağlantı kurma becerilerini, 37 sınıf öğretmeni kendi düşüncelerini kanıtlarla desteklemeyi, 26 sınıf öğretmeni bilimsel bilginin üretilme sürecini görmesini, 23 sınıf öğretmeni problem çözme becerilerini, 32 sınıf öğretmeni kendisinin ve diğerler arkadaşlarının düşüncelerini sorgulama becerilerini, 30 sınıf öğretmeni öğrencilerin düşüncelerini savunma becerilerini, 14 sınıf öğretmeni öğrencilerin bakış açılarını, 32 sınıf öğretmeni ise tartışma becerilerini ve bilim okuryazarlığını geliştireceğini belirtmişlerdir .

4. Araştırma sorularından dördüncüsü, "Sınıf öğretmenlerine göre argümantasyon yönteminin sinırlılıkları nelerdir?" sorusudur. Buna göre, sınıf öğretmenlerinin argümantasyon yönteminin sınırlılıkları hakkındaki görüşleri değerlendirildiğinde: 12 sınıf öğretmeninin çok zaman aldığını, 13 sınıf öğretmeninin bütün konularda kullanılamayacağını, 11 sınıf öğretmeninin tartışma konusunun sınırları çizilmediğinde konu dışına çıkılabileceğini, 12 sınıf öğretmeninin ön bilgi eksikliği durumunda bu yöntemin uygulanmasının başarısız olacağını, 11 sınıf öğretmeninin de sınıf mevcudunun fazla olması halinde uygulamanın zorlaşacağını belirttikleri izlenebilir.

5. Araştırma sorularından beşincisi, "Sınıf öğretmenlerinin argümantasyon yöntemini ders veya derslerde kullanmaya yönelik düşünceleri nelerdir?" sorudur. Buna göre sinıf öğretmenlerinin ilgili soruya yönelik görüşleri şunlardır; 8 sınıf öğretmeni bu yöntemin sadece fen bilimleri dersinde kullanılabileceğini ifade ederken; 29 sınıf öğretmeni ise (fen bilimleri 29, matematik 23, hayat bilgisi ve sosyal bilgiler 29, Türkçe, 15 sınıf öğretmeni) bu yöntemin fen bilimleri dışında diğer derslerde de kullanılabileceğini belirtmişlerdir.

\section{Sonuç ve Tartışma}

Sınıf öğretmenlerinin 3. ve 4. sınıf fen bilimleri dersinde argümantasyon yönteminin kullanımına ilişkin görüşlerinin belirlenmeye çalışıldığı bu araştırmada elde edilen bulgular aşağıdaki gibi tartışılmıştır.

1. Araştırma sorularından birincisi, "Sınıf öğretmenlerinin argümantasyon yöntemi hakkında bilgi düzeyleri nedir?" sorusudur. Tablo 1 incelendiğinde çalışmaya katılan sınıf öğretmenlerinin argümantasyon yönteminin adını ilk defa duydukları ve bu yöntem 
hakkında bilgi sahibi olmadıkları ve bu yöntem hakkında bilgi sahibi olmak istedikleri görülmektedir.

2. Araştırma sorularından ikincisi, "Sınıf öğretmenlerinin argümantasyon yöntemiyle ilgili eğitim alma durumları nedir?" sorusudur. Tablo 1 incelendiğinde sınıf öğretmenlerinin farklı yöntemlerle eğitim aldıkları; ancak argümantasyon yöntemi ile ilgili daha önce eğitim almadıkları, bu eğitim sürecinin argümantasyon yöntemi ile ilgili ilk eğitim olduğunu ve sürecin çok faydalı olduğunu belirttikleri fark edilmektedir. Driver, Newton ve Osborne da (2000) argümantasyon yönteminin derslerde etkin bir şekilde kullanılması için öğretmenlerin eğitim almaları gerektiğini belirtmiş ve argümantasyon sürecinin önemine gönderme yapmışlardır.

3. Araştırma sorularından üu̧üncüsü, "Sınıf öğretmenlerine göre argümantasyon yönteminin avantajları nelerdir?" sorusudur. Tablo 1 incelediğinde, sınıf öğretmenlerinin argümantasyon yönteminin öğrencilerin bilişsel yapılarına katkılarına ilişkin olumlu görüş bildirdikleri görülmektedir. Buna göre argümantasyon sürecinin, öğrencilerin ön bilgilerinin ortaya çıkarılmasında, değerlendirilmesinde, kendi düşüncelerini başkalarının düşünceleriyle karşılaştırmalarında, dikkatlerinin yoğunlaştırılmasında, güdülenmesinde, araştırma becerilerinin gelişiminde, anlamlı ve kalıcı öğrenmede, kavram yanılgılarının giderilmesinde ve kavram öğretiminde katkıda bulunacağı açıktır. Çalışmamızın bulguları, Kaptan ve Aydın (2014), Kaya ve Kılıç (2008), Kıngır, Geban ve Günel (2011), Michaels, Schweingruber ve Shouse (2008), Tümay ve Köseoğlu ( 2011), Yıldırır ve Nakiboğlu'nun (2014) yapmış olduğu araştırma sonuçları ile uyumluluk göstermektedir.

$\mathrm{Bu}$ yöntemin sosyal katkılarına yönelik öğretmen görüşlerinin; öğrencilerin kendilerini ifade etme becerilerini geliştireceği, sosyalleşmesini sağlayacağı̆, iletişim becerilerini geliştireceği, birbirlerini dinlemelerini sağlayacağı, birbirlerini ikna ederek düşüncelerinin değişmesini sağlayacağı, toplum önünde konuşma becerilerini geliştirmeye katkı bulunacağı şeklinde olduğu görülmektedir. Ulaşılan öğretmen görüşlerinin; Kaptan ve Aydın (2014), Kıngır, Geban ve Günel (2011), Simon, Erduran ve Osborne (2006); Tümay ve Köseoğlu'nun (2011) yapmış olduğu araştırma bulgularından biri olan, "argümantasyon yöntemi sosyal becerilerinin gelişimine katkıda bulunur." önermesini desteklediği belirtilebilir.

Argümantasyon yönteminin duyuşsal katkılarına yönelik öğretmen görüşlerinin; argümantasyonun, eğitim ve öğretim sürecini tekdüzelikten kurtarıp dersi zevkli, eğlenceli, 
ilgi çeki hale getirip öğrencilerin olumlu tutum geliştirmelerini sağlayacağı, öğrencilere tartışmanın nasıl yapılması gerektiğini öğreteceği, öğrencilerin özgüvenini arttıracağı, birbirlerinin fikirlerine değer vermelerini sağlayacağı ve yine öğrencilerin eleştiriye açık olmalarını sağlayacağı şeklinde olduğu ifade edilebilir. Bu yöndeki öğretmen görüşleri bazı araştırmaların bulguları örtüşmektedir (Kaptan \& Aydın, 2014; Kıngır, Geban \& Günel, 2011; Hang, Wallece \& Yang, 2004; Tümay \& Köseoğlu, 2011; Yıldırır \& Nakiboğlu,2014).

Argümantasyon yönteminin bilimsel düşünme becerilerini geliştirmeye yönelik katkılarına yönelik öğretmen görüşlerinin; öğrencilerin konuşma becerilerini, bilimsel süreç becerilerini, üst düzey düşünme becerilerini, akıl yürütme becerilerini, problem çözme becerilerini, iddialarla kanıtlar arasında bağlantı kurma becerilerini, kendi düşüncelerini kanıtlarla destekleme becerilerini, kendisinin ve diğerler arkadaşlarının düşüncelerini sorgulama becerilerini ve fen okuryazarlığını geliştireceği yönünde olduğu belirtilebilir (Tablo 1). Bu bulguya ait öğretmen görüşleri de bazı araştırmacıların (Demircioğlu \& Uçar, 2012; Driver, Osborne \& Newton, 2000)-; Erduran, Osborne \& Simon, 2004; Kaptan \& Aydın, 2014; Kaya \& Kılıç, 2008; Tümay \& Köseoğlu, 2011) vurguladıkları “argümantasyon yöntemi bilimsel düşünce becerilerinin gelişmesinde etkili bir yöntemdir." önermesiyle uyum içinde olduğu belirtilebilir.

4. Araştırma sorularından dördüncüsü, "Sınıf öğretmenlerine göre argümantasyon yönteminin sınırlılıkları nelerdir?" sorusudur. Sınıf öğretmenlerinin argümantasyon yönteminin sınırlılıkları hakkındaki görüşlerinin; yöntemin çok zaman aldığı, tüm konu başlıkları için uygun olamayacağı, tartışma konusunun sınırları çizilmediğinde konu dışına çıkılabileceği, ön bilgi eksiği durumunda yöntemin uygulanmasının başarısız olacağı, sınıf mevcudunun fazla olması halinde yöntemi uygulamanın zorlaşacağı yönünde olduğu görülebilir (Tablo 1). Çalışmamızda ortaya çıkan öğretmen görüşlerinin, Çepni (2016), Demircioğlu ve Uçar (2012) ve Kaptan ve Aydın'ın (2014) yapmış olduğu araştırmalarda ortaya çıkan "argümantasyon yönteminin sınırlılıkları" na yönelik bulgularla benzerlik taşıdığg ifade edilebilir.

5. Araştırma sorularından beşincisi, "Sınıf öğretmenlerinin argümantasyon yöntemini derslerde kullanmaya yönelik düşünceleri nelerdir?" sorusudur. Öğretmenlerin argümantasyon yönteminin derslerde kullanımına yönelik görüşleri; 29 öğretmen dışında, yöntemin yalnızca fen bilimleri derslerinde kullanılabileceği yönünde olmuştur (Tablo 1). Kaya \& Kılıç (2008), Tümay \& Köseoğlu (2011); Driver, Newton \& Osborne da (2000) 
yürüttükleri araştırmalarda, fen bilimleri eğitimde argümantasyon yönteminin kullanılması gereken etkin bir öğretim yöntemi olduğunu belgelemişlerdir. Torun \& Şahin'in (2016) sosyal bilgiler, Doruk, Duran \& Kaplan'ın (2017) matematik, Ekici \& Bilici'nin (2017) hayat bilgisi derslerinin öğretimine yönelik çalışmalarda, argümantasyon yöntemi lehine başarılı sonuçlar sağlamaları; argümantasyon yönteminin fen bilimleri dersi öğretimi dışında da kullanılabileceğinin bir işareti olarak değerlendirilebilir. Sonuç olarak, çalışmanın bulguları 1şığında aşağıdaki önerilerde bulunulabilir..

\section{Öneriler}

Argümantasyon yöntemi sadece fen bilimleri dersinde değil, diğer derslerde de kullanılabilir.Yöntemin tam olarak bilinmeden uygulanması başarısızlıkla sonuçlanabilir. Bundan dolayı öğretmenlere, 2017 fen bilimleri dersi öğretim programında özellikle vurgulanan argümantasyon yöntemine yönelik teorik ve uygulamalı eğitim verilmesi düşünülebilir. Ülkemizde İlkokul düzeyinde argümantasyon yönteminin kullanılmasıyla ilgili çok az çalışma yapıldığı görülmektedir. Dolayısıyla, yöntemin uygulanmasına ilişkin araştırma sayının arttırılması hususundaki yeni çalışmalarla farkındalık oluşturulabilir.

\section{Kaynaklar}

Apaydın, Z., Peker, E. \& Taş, E. (2012). Isı yalıtımını argümantasyonla anlama: İlköğretim 6. sınıf öğrencileri ile durum çalışması. Dicle Üniversitesi Sosyal Bilimler Enstitüsü Dergisi, 4 (8), 79-100.

Aykaç, N. (2005). Öğrenme ve öğretim sürecinde aktif öğrenme yöntemleri. Ankara: Naturel Yayıncilik.

Aykaç, N. (2011). Hayat bilgisi dersi öğretim programında kullanılan yöntem ve tekniklerin öğretmen görüşlerine göre değerlendirilmesi (Sinop İli Örneği ). Kastamonu Ĕ̆itim Dergisi, 19 (1), 113-126.

Aldağ, H. (2006). Toulmin tartışma modeli. Çukurova Üniversitesi Sosyal Bilimler Enstitüsü Dergisi, 15(1), 13-34.

Büyüköztürk, Ş., Çakmak, E. K., Akgün, Ö. E., Karadeniz, Ş. \& Demirel, F. (2016). Bilimsel araştırma yöntemleri. Ankara: Pegem Akademi Yayıncılık.

Çepni, S. (2010). Araştırma ve proje çalışmalarına giriş. Trabzon: Celepler Matbaacılık.

Çepni, S. (2016). Fen ve teknoloji öğretimi. Ankara: Pegem Akademi.

Demircioğlu, T. \& Ucar, S. (2012). The effect of argument-driven inquiry on pre-service science teachers' attitudes and argumentation skills. Procedia-Social and Behavioral Sciences, 46, 5035-5039.

Driver, R., Newton, P. \& Osborne, J. (2000). Establishing the norms of scientific argumentation in classrooms. Science Education, 84 (3), 287-312. 
Duran, M., Doruk, M. \& Kaplan, A. (2017). Argümantasyon tabanlı olasılık öğretiminin ortaokul öğrencilerinin başarılarına ve kaygılarına etkililiğinin incelenmesi. Eğitimde Kuram ve Uygulama, 13(1), 55-87.

Ekici,G. \& Bilici, H. I. (2017). İlkokul öğrencilerinin "yuva” kavramina ilişkin bilişsel yapıları: hayat bilgisi dersinde nitel bir analiz örneği. Journal of Computer and Education Research, 5 (9), 1-30.

Erduran, E., Simon, S. \& Osborne, J. (2004). Tapping into argumentation: developments in the application of toulmin's argument pattern for studying science discourse. Science Education, 88 (6), 915-933.

Kaptan, F. \& Aydın, Ö. (2014). Fen-teknoloji öğretmen adaylarının eğitiminde argümantasyonun biliş üstü ve mantıksal düşünme becerilerine etkisi ve argümantasyona ilişkin görüşler. Ĕ̆itim Bilimleri Araştırma Dergisi, 4 (2), 163-188.

Kaya, O. N. \& Kılıç, Z. (2008). Etkin bir fen öğretimi için tartışmacı söylev. Ahi Evran Üniversitesi Kırşehir Eğitim Fakültesi Dergisi, 9 (3), 89-100.

Kıngır, S., Geban, Ö.\& Günel, M. (2011). Öğrencilerin kimya derslerinde argümantasyon tabanlı bilim öğrenme yaklaşımının uygulanmasına ilişkin görüşleri. Selçuk Üniversitesi Ahmet Keleşoğlu Eğitim Fakültesi Dergisi, 32, 15-28.

Köseoğlu, F., Tümay, H. \& Budak, E. (2008). Bilimin doğası hakkında paradigma değişimleri ve öğretimi ile ilgili yeni anlayışlar. Gazi Üniversitesi Gazi Ĕ̆itim Fakültesi Dergisi, 28 (2), 221-237.

Michaels, S., Shouse, A., W. \& Schweingrber, H., A. (2009). Ready, set science! Putting research to work in k-8 classroms. Washington, D.C. National Academies Press. Erişim adresi:

https://www.google.com.tr/search?q=michaels\%2C+shouse $\% 2 C+$ schweingrber + pdf\&oq=m\&aqs=chrome.0.69i59j69i6013j69i57j35i39.1915j0j8\&sourceid= chrome\&ie=UTF-8 adresinden 1 Ağustos 2017 indirilmiştir.

Miles, M.B. \& Huberman, A.M. (1994). Qualitative data analysis. Thousand Oaks, CA: Sage.

Hançer, A., H., Şensoy, Ö. \& Yıldırım, H., İ. (2003). İlköğretimde çağdaş fen bilgisi öğretiminin önemi ve nasıl olması gerektiği üzerine bir değerlendirme. Pamukkale Üniversitesi Ĕ̆itim Fakültesi Dergisi, 13, 80-88.

Hand, B. Wallace, C. \& Yang, E. (2004). Using the science writing heuristic to enhance learning outcomes from laboratory activities in seventh grade science: Quantitative and qualitative aspects. International Journal of Science Eduation, 26, 131-149.

Hemlick, J. E. \& Norland, E. V. (1994). I do believe... in Santa? (Cover Story). Adult Learning, $3(5), 22-24$.

Torun, F. \& Şahin, S. (2016). Argümantasyon temelli sosyal bilgiler dersinde öğrencilerin argüman düzeylerinin belirlenmesi. Ĕ̆itim ve Bilim, 41 (186), 233-251.

Tümay, H. \& Köseoğlu, F. (2011). Kimya öğretmen adaylarının argümantasyon odaklı öğretim konusunda anlayışlarının geliştirilmesi. Türk Fen Eğ̈itimi Dergisi, 8 (3), 105120.

Simon, S., Erduran \& S., Osborne, J. (2006). Learning to teach argumentation: research and development in the science classroom. International Journal of Science Education, 28 (2), 235-260. 
Toulmin, S. E. (2003). The uses of argument. Cambridge: Cambridge University Press

Türkben, T. (2015). Aktif öğrenme yöntemiyle oluşturulmuş sınıf ortamının öğrenciler üzerisindeki etkisi. International Periodical For The Languages, Literature and History of Turkish or Turkic,10 (7), 899-916.

Yıldırır, H. E. \& Nakiboğlu, C. (2014). Kimya öğretmen ve öğretmen adaylarının derslerinde kullandıkları argümantasyon süreçlerinin incelenmesi. Abant İzzet Baysal Üniversitesi Ĕ̆itim Fakültesi Dergisi, 14 (2), 124-154.

Yıldırım, A. \& Şimşek, H. (2008). Sosyal bilimlerde nitel araştırma yöntemleri. Ankara: Seçkin Yayınları

Saygılı, G. (Ed.). (2015). Illkokulda kullanılan strateji, yöntem ve teknikler. Ankara: Pegem Akademi. 